\title{
ペーパークロマトクラフィーによる脂肪族アルテヒドの分析法† \\ 付ナタネ油を酸化したとき生ずる揮発性カルボニル化合物
}

（昭 和 38 年 6 月 4 日 受 理)

\author{
鈴木義仁*・武内次夫* 丸田 鈴二朗**
}

脂肪族アルデヒドの 2,4-DNPH を口紙に付着させ, $\mathrm{P}$ を固定相として 0:08〜0. $10 \mathrm{~g} / 100 \mathrm{~cm}^{2}$ 吹籍し, 上年法で $30^{\circ} \mathrm{C}$ の恒温室中で展開剤として M.P. (20:3)(混合比：容積）を用いてぺーパークロマトクラフィーを行なった。分離した斑 点を吸光度最大の点に固定し口紙上で直接紫外吸収スペクトルを測定した。飽和アルデヒドの 2, 4-DNPHは $370 \mathrm{~m} \mu$ に, 不飽和モノエンフルデヒド $\left(\Delta^{2}\right)$ の $2,4-\mathrm{DNPH}$ は $385 \mathrm{~m} \mu$, 不飽和シェンンルデヒド $\left(\Delta^{2,4}\right)$ の $2,4-\mathrm{DNPH}$ は $405 \mathrm{~m} \mu$ に吸光度の極大があった。溶液（ペンゼン）として吸収スペクトルを測定した場合に比べて約 $12 \sim 15 \mathrm{~m} \mu$ 吸収の極大波 長は長波長側にシフトした。しかしながら $370 \mathrm{~m} \mu$ における吸光度は飽和, 不飽和 $\left(\Delta^{2}, \Delta^{2,4}\right)$ のフルデヒドの種類に関 係なく一定のモル吸光度を示すことを見出した。フルデヒドの $2,4-\mathrm{DNPH}$ の混合物のペーパークロマトクラフィーを行 なった結果から，同一炭素数の飽和扣よび不飽和の差による斑点の分離は括こらず，従って $370 \mathrm{~m} \mu$ の波長を用いて測 定したパピログラフより吸光度曲線下の斑点面積を求めると，付着した試料中の炭素数の差による分離分析が行なえた。 次にそれぞれの炭素数別によって分離した斑点について $310 \sim 450 \mathrm{~m} \mu$ の紫外吸収スペクトル（口紙上で）を測定し，上 記した 3 成分の特性波長の吸光度を求めて斑点中の混合物の共存分析を行なった。

本報は微量試料で混合物中の炭素数別の分離と, 分離した斑点中の飽和, 不飽和混合物の分析が同時に行なえる利点が ある。

\section{1 腥言}

油脂の臭いの戻りに関して研究する目的で，油脂中に微量に存 在するカルボニル化合物あるいは酸化変敗によって生成するとこ ろのカルボニル化合物を検索する必要が生じた。既報1)でこれら

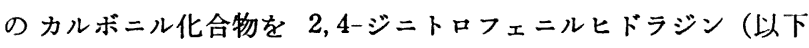
2, 4-DNP と略記する) の誘導体として, ベンゼン溶液中で紫外 吸収スペクトルを測定し, 飽和カルボニル化合物と不飽和カルボ ニル化合物（モノェン）とを定量した。また異なる炭素数のカル ボニル化合物の混合試料の場合にはペーパークロマトグラフィー を行なって炭素数の違いによる $R_{f}$ 值の差で分離し, 备分離斑点 を抽出して紫外吸収スペクトルを測定して定量する方法について 述べた。しかしながら抽出操作を行なら久点と溶液として吸収ス ペクトルを測定するには, ペーパークロマトグラフィーに比して かなりの量を必要とした。従って数回のペーパークロマトグラフ ィーを行なって，分離した斑点を抽出する方法をとらねばならな かった。

本報では，脂肪族アルデヒドの 2,4-ジニトロフェニルヒドラ ゾン（以下 2,4-DNPH と略記する）をペーパークロマトグラフ ィーし, 分離した斑点について, $370 \mathrm{~m} \mu$ の波長に打ける吸光度 曲線下の斑点面積を島津分光光度計付属装置を用いて測定した。

斑点面積と吸光度とは試料の展開用口紙に付着させた量に比例 し, 混合アルデヒド試料の 2,4-DNPH について分離定量ができ た。次に展開用口紙上で分離した各斑点について, その吸光度最 大の点に固定して 310 450 $\mathrm{m} \mu$ の波長範囲の吸収スペクトルを 測定した。分離した斑点中の飽和アルデヒドの 2,4-DNPH と不 飽和アルデヒドの 2,4-DNPH とが溶媒法ほどの精度はないが微

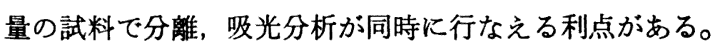

†本報を「脂肪族アルテヒドの分析法（その3）」とする. 第 2 報は, 油化学 12,44 (1963).

* 名古屋大学工学部工業分析化学教室 : 名古屋市千種区不老 町.

** 山梨大学学芸学部化学教室 : 甲府市武田 4 丁目.

1) 丸田, 鈴木, 工化 64,2129 (1961).
ナタネ油に空気を送入し， $96^{\circ} \mathrm{C}$ に加熱した時生ずるカルボニ ル化合物を 2,4-DNP 誘導体として捕捉し，本法を用いて分析し た結果についても報告する。

\section{2 实験および結果の考察}

\section{$2 \cdot 1$ 試 料}

$2 \cdot 1 \cdot 1$ 飽和アルテヒドおよび不飽和モノェンアルデヒド 試 料として使用した飽和アルデヒド掞よび不飽和モノエンアルデヒ ドは市販品を精留し，所定の沸点区分を試料とするか，既報1)の ような方法で, 合成したものである。これらのアルデヒドからの 2,4-DNPH の合成は既報1) と全く同じ操作を行なって誘導体と し，精製をした。

$2 \cdot 1 \cdot 2$ 不飽和ジエンアルデヒト 不飽和ジェンアルデヒドは 次の方法で合成した。へキナ-2,4-ジェナールは, 市販のソルビ ン酸を窒素ガスの存在下で,メチルェステルとしたのち減圧分留 し, 所定の沸点部分を集め, これをェーテル溶液とした。これに リチウムアルミニウム四水素化物のエーテル溶液を滴加して還元 した。得られるソルビルアルコールを石油エーテルにとかしこ れに新しく合成した活性二酸化マンガン粉末2)を加え, 室温でか きまぜて酸化させ, へキサ-2,4-ジェナールとした。他のジェナー ルはいずれも次の二方法で合成した。すなわち, Pippen ら)の 合成法と同様に, 1-ブトキシ-1-ブテン-3-イン※1と飽和アルデヒ ドとを縮合させて得た。またこの方法とは別に既報1てで合成した 不飽和モノェンアルデヒドをピリジン溶液とし，これにマロン酸 モノメチルを加えてピペリジンを触媒とし縮合させた。得られた ジェン酸をエーテル溶液とし、リチウムアルミニウム四水素化物 で還元した。この後の操作は前記したへキサ-2,4-ジェナールの 合成法と同様である。

2) 日本化学会編, “実験化学講座 (17), 有機化合物の反応 I (上)”, 丸善 (1956) p. 571 .

3) E. L. Pippen, M. Nonaka, J. Org. Chem. 23, 1580 (1958).

※1 1-ブトキシ-1-ブテン-3-インは Pippen の好意で贈与され たすのである。 
このよ5にして得た粗製のジェンアルデヒドは减圧下で窒素ガ ス気流中で分留し,所定沸点部分を集め,ただちに 2,4-DNPH 誘 導体とした。このジェンアルデヒドの 2, 4-DNPH はェタノール から再結晶したのち, アルミナ充填カラム $(2.5 \mathrm{~cm} \times 40 \mathrm{~cm})$ 中 をベンゼンで展開し精製した。

\section{$2 \cdot 2$ 紫外吸收スペクトル}

$2 \cdot 1 \cdot 1$ 拈よび 2.1.2 で得た飽和アルデヒド，不飽和モノェン アルデヒド $\left(\Delta^{2}\right)$ 扰よび 不飽和ジェンアルデヒド $\left(\left(\Delta^{2}, 4\right)\right.$ 等の 2,4-DNPH を精科し，ベンゼン溶液とした。この溶液について $300 \sim 420 \mathrm{~m} \mu$ の波長範囲の吸収スベクトルを測定した。飽和ア ルデヒドの 2,4-DNPH は $358 \mathrm{~m} \mu$ に吸収極大を示し,この波長 に扣壮る分子吸光度は 20,500 であった。不飽和モノェンアルデ ヒド ( $\left.\Delta^{2}\right)$ の 2,4-DNPH は $373 \mathrm{~m} \mu$ に吸収の極大が, $312 \mathrm{~m} \mu$ 付近に吸収の極小があった。極大吸収のある $373 \mathrm{~m} \mu$ に打ける 分子吸光度は 23,000 であった。また，不飽和ジェンアルデヒド $\left(\Delta^{2,4}\right)$ の 2,4-DNPH は $390 \mathrm{~m} \mu$ に極大吸収があり, $325 \mathrm{~m} \mu$ に 吸収の極小があった。極大吸収を示す $390 \mathrm{~m} \mu$ に打ける分子吸 光度は 34,000 であった。これらの結果は Pippen ${ }^{3)}$, Johnson4) らの報告の結果に一致した。従って本報告に, これらのアルデヒ ドの 2,4-DNPH を基準物質として使用した。また飽和アルデヒ ド呿よび不飽和モノェンアルデヒド $\left(\Delta^{2}\right)$ の 2,4-DNPH につい ては著者の報告がある1。

\section{$2 \cdot 3$ 口紙上で分離した斑点の吸収スペクトル}

$2 \cdot 1 \cdot 1$ および 2.1.2 で合成したアルデヒドの 2,4-DNPH を はかり取り，ベンゼンにとかして $2 \sim 5 \mathrm{mg} / \mathrm{ml}$ 程度の 濃度とし た。この溶液をペーパークロマト用特製ミクロピペットで 0.01 $\sim 0.05 \mathrm{~m} l$ とり, 東洋濾紙 No. $50(2 \times 40 \mathrm{~cm})$ の下端より 5 $\mathrm{cm}$ のところに付着した。付着させる際斑点の直径が $5 \mathrm{~mm}$ 以 上に拡がらぬようにした。展開溶媒としてメタノール（以下 $\mathrm{M}$ と略記) : 石油岸化水素 bp $140 \sim 170^{\circ} \mathrm{C}$ (以下 $\mathrm{P}$ と略記) $=20: 3$ （容量比）を用い，Pを固定相として，口紙に対して $0.08 \sim 0.10$ $\mathrm{g} / 100 \mathrm{~cm}^{2}$ のわりで噴霧した。 $30^{\circ} \mathrm{C}$ にたもった恒温室中で上昇 法で展開した。溶媒先端が約 $20 \mathrm{~cm}$ 移動したとき装置内より,と ク出して風乾した。各アルデヒドの炭素数に応じて分離した口紙 上の斑点について, 島津分光光度計の付属装置に取付けて 310 $450 \mathrm{~m} \mu$ の波長範囲での吸収スペクトルを測定した。その結果を 図1に示した。

図1には一例としてへキサナール 2,4-DNPH，へキサ-2-エナ ール 2,4-DNPH，ヘキサ-2,4-ジェナール DNPH の斑点の吸収スペクトルを示した。 図1より明らかなように飽和アルデヒドの 2,4-DNPH は $370 \mathrm{~m} \mu$ に吸収極大があり, 不飽和モノェンアルデヒドの 2,4-DNPH は $385 \mathrm{~m} \mu$ に，また不飽和ジェンアルデ ヒドは $405 \mathrm{~m} \mu$ 付近に吸収極大を示した。 口紙上で分離した斑点の紫外吸収スペクト ルの結果は溶媒中 (ペンゼン) での紫外吸 収スペクトルに比べて極大吸収を示す波長 が約 $12 \sim 15 \mathrm{~m} \mu$ 程度長波長側にずれて現 われた。展開溶媒の種類や定性分析用の口

4) G. D. Johnson, J. Am. Chem. Soc. 75,2720 (1953).

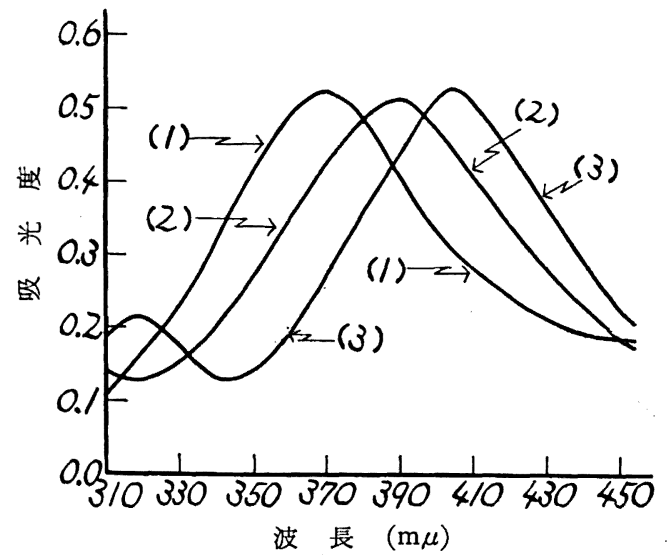

因 1 斑点の紫外吸収スペクトル

(1): $n$-ヘキサナール 2,4-DNPH $\mid$ とついての東洋波紙 No. 50 上で分

(2) : $n$-ヘキサモノェナール"

紙（たとえば東洋濾紙 No. 2) を用いると吸収曲線を示すカーブ が多少異なった。たとえば斑点の分離能のよい $\mathrm{M}, \mathrm{A}$ (酢酸)， $\mathrm{T}$ (テトラリン)の混合展開溶媒を用いた場合吸収極大を示す波長 は一致したが，吸収曲線がシャープでなく平らたくなり飽和アル デヒドと不飽和アルデヒドとを区別するのに良好ではなかった。

$2 \cdot 3 \cdot 1$ 付着量と吸光度との関係 $2 \cdot 1 \cdot 1,2 \cdot 1 \cdot 2$ て得た各種類 のアルデヒドの 2,4-DNPH を精科し, $10 \mathrm{~m} l$ 容のメスフラスコ 中に移しベンゼン溶液として種々の濃度のるのを調製した。この 中より 2,4-DNPH として $0 \sim 2.5 \mathrm{mmol} \times 10^{-5}$ 程度存在するよ ろにミクロピペットで正確にロ紙に付着した。M.P. (20:3)でP を固定相とする逆相法で展開した後, 装置内よりとり出し風乾し た。各斑点の最大吸光度を示す位置に口紙を微動させて調節し固 定した。310〜 450 m $\mu$ の波長範井の吸収スペクトルを測定した。 各斑点の吸収極大波長に持ける吸光度と口紙に付着したアルデヒ ドの 2,4-DNPH 量との関係は図 2 のと沏りであった。

因 2 の吸収極大波長 $370 \mathrm{~m} \mu, 385 \mathrm{~m} \mu$ および $405 \mathrm{~m} \mu$ におけ る吸光度と試料のモル数との関係を検量線図とする。図 2 より明 らかなよ5に $370 \mathrm{~m} \mu$ における吸光度は飽和アルデヒドであっ ても，不飽和アルデヒドであっても，モル数が同じならば一定の吸 光度を与えることがわかった。この場合, 十分の注意 (2.3で記 述したように）を行なわないと良好な再現性は得られない。また 試料濃度に極端な高低がある場合も困難であった。

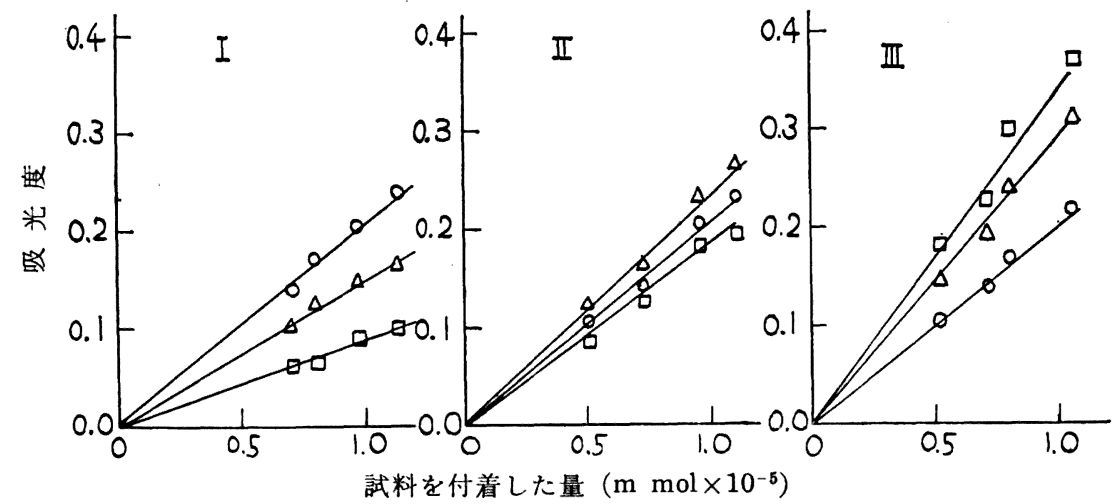

困 2 脂肪族アルデヒド $2,4-\mathrm{DNPH}$ の付着量と吸光度との関係

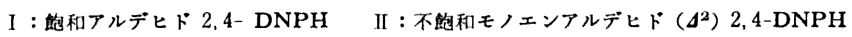
III：不蚼和ジェンアルデヒド $\left(\Delta^{2}, 4\right) 2,4-D N P H$

○印は $370 \mathrm{~m} \mu, \triangle$ 印は $385 \mathrm{~m} \mu$ ，口印は $405 \mathrm{~m} \mu$ での吸光航を示す。 
$2 \cdot 3 \cdot 2$ パピログラ 2.3.1 で述べたこととくロ紙上で分離し た斑点の吸収スペクトルを測定したところ, 飽和アルデヒドの 2 , 4-DNPH と,不飽和アルデヒドの 2, 4-DNPH とは, $370 \mathrm{~m} \mu$ の 波長に拈けるモル吸光度は一致した。このことは $370 \mathrm{~m} \mu$ の波 長を用いて 飽和アルデヒドの 2, 4-DNPH と不飽和アルデヒド の 2,4-DNPH との混合物を, ペーパークロマトリ゙ラフィーを行 なって（炭素数の異なりによる）分離した斑点についてロ紙上で 吸光度を測定すれば，飽和・不飽和の区別なく，付着した試料中 の炭素数に応じてのパピログラムが得られることを示唆してい る。

図3に混合物のパピログラムを示した。図 3 は $\mathrm{C}_{4} \sim \mathrm{C}_{12}$ までの 飽和アルデヒド执よび不飽和アルデヒドの 2,4-DNPH の混合溶 液を調製し，ミクロピペットで $0.01 \mathrm{ml}$ を付着させ，展開後島 津分光光度計付属装置を用い実験に使用した口紙片を補償紙とし て試料を付着した位固（原線）より口紙を $2 \mathrm{~mm}$ 間隔で, 移動 させ， $370 \mathrm{~m} \mu$ の波長に批汁るパピログラム(口紙上に分離した 斑点の桩がりと吸光度の関係）を求めた。

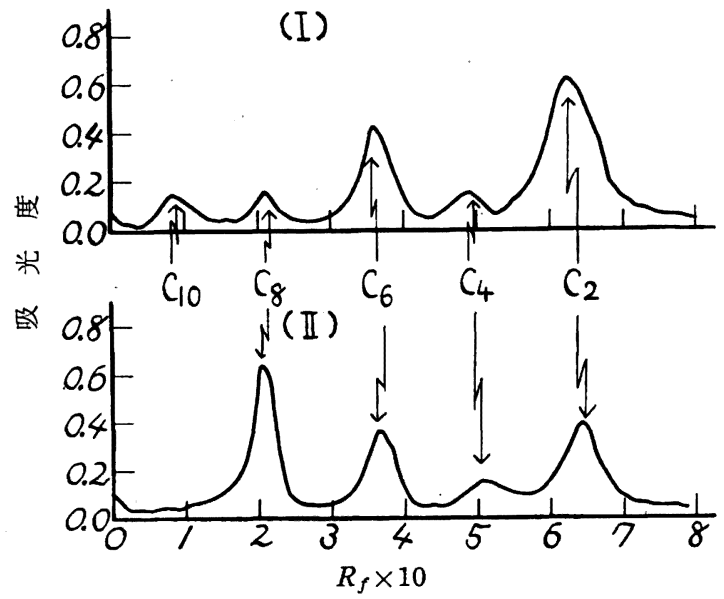

因 3 混合試料のパピログラム

（I）は飽和アルデヒト $\mathrm{C}_{2}, \mathrm{C}_{4}, \mathrm{C}_{8}, \mathrm{C}_{8}, \mathrm{C}_{10}$ の混合科料 (II) 仕 $\mathrm{C}_{8}^{0}, \mathrm{C}_{8}^{\wedge: 2}, \mathrm{C}_{8}^{0}, \mathrm{C}_{6}^{\Delta: 2: 4}, \mathrm{C}_{4}^{0}, \mathrm{C}_{4}^{\Delta: 2}, \mathrm{C}_{2}^{0}$ の混合部料

(注) $\mathrm{C}_{8}^{0}$ は二重結合 0 で岸絭数 8 のアルデヒドを, $\mathrm{C}_{8}^{\Delta: 2}$ は二 重結合の存在位羁とその個数を（：）で示し，笑来数 8 の アルデヒドを示す。

図3から明らかなように，炭素数の異なるアルデヒドの 2,4DNPH の分離は明瞭であるが, 同数の炭素数のアルデヒドで, 飽和のものと不飽和のものとの差はあらわれていない。

次に種々の混合割合の試料を調製して，口紙への付着量と 370

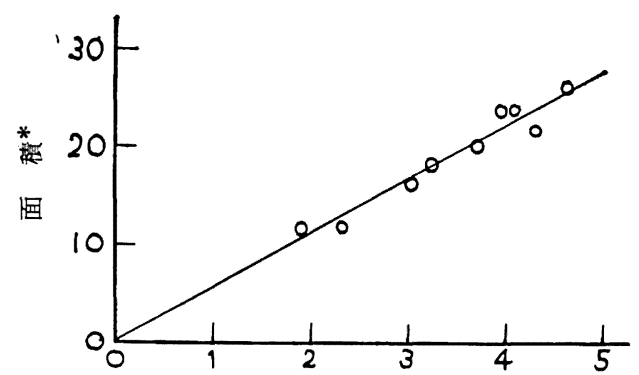

付着した量 $\left(\mathrm{mmol} \times 10^{-5}\right)$

因 4 付着量と面積との関係

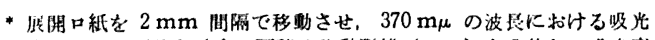

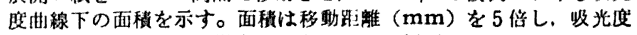

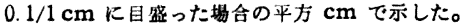

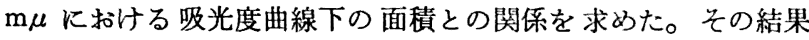
は，図4のと括りであった。

図 4 は付着した量と混合試料中の各アルデヒドに応じて分離し た斑点面積は比例することがわかった。これを混合武料の場合の 検量線因とする。

従って，アルデヒドの 2,4-DNPH 混合陚料についてペーパー クロマトグラフィーを行ない分離した斑点について $370 \mathrm{~m} \mu$ の波 長に扣ける吸光度を求め, $R_{f}$ 值より相当するアルデヒドとして の斑点のパピログラフ曲線下の面積を求めることによって混合試 料中のアルデヒドの存在量が求められる。

$2 \cdot 3 \cdot 3$ 調合試料の分析 図 3 より明らかなよ5に, 同数の炭 素数の飽和アルデヒドと不飽和アルデヒドの 2,4-DNPH の混合 物々は全く分離しなかった。これらの混合物より得られる斑点は 単一物質のようなパピログラフを与えた。しかしながら（2·3・1， 因 1) に記したように，斑点中のそれぞれのアルデヒドの 2,4DNPH について求めた各波長のモル吸光度より次に示寸関係式 が得られた。各アルデヒドの飽和，不飽和によって示される特性 波長 $(370 \mathrm{~m} \mu, 385 \mathrm{~m} \mu, 405 \mathrm{~m} \mu)$ の外に計算上の精度を高める ために, $350 \mathrm{~m} \mu$ と $420 \mathrm{~m} \mu$ の波長に打ける濃度と吸光度との 閨係を求めた。

$$
\begin{aligned}
& 10^{3} \cdot A_{350}=163 S+124 U_{1}+116 U_{2} \\
& 10^{3} \cdot A_{370}=205 S+205 U_{1}+205 U_{2} \\
& 10^{3} \cdot A_{385}=145 S+230 U_{1}+300 U_{2} \\
& 10^{3} \cdot A_{405}=85 S+185 U_{1}+345 U_{2} \\
& 10^{3} \cdot A_{420}=61 S+145 U_{1}+313 U_{2}
\end{aligned}
$$

$A_{350}, A_{370}, A_{385}, A_{405}$ 扩よび $A_{420}$ はそれぞれ 350,370, $385 ， 405$ および $420 \mathrm{~m} \mu$ の各波長に括ける口紙上で分離した斑 点の吸光度， $S, U_{1}$ 㧊よび $U_{2}$ は，それぞれ飽和アルデヒド， 不飽和モノェン $\left(\Delta^{2}\right)$ ，打よびジェンアルデヒド $\left(\Delta^{2,4}\right)$ の 2,4 DNPH の m mol である。斑点の各波長に拈ける吸光度を測定 し, 上式に代入して，最小自乗法で誤差を最小とする $S, U_{1}, U_{2}$ を求めればよい。

表 1 に $\mathrm{C}_{6}$ の飽和拈よび不飽和アルデヒド $\left(\Delta^{2}\right)$ の調合試料を 分析した結果を示した。

表 1 調合試料の分析結果

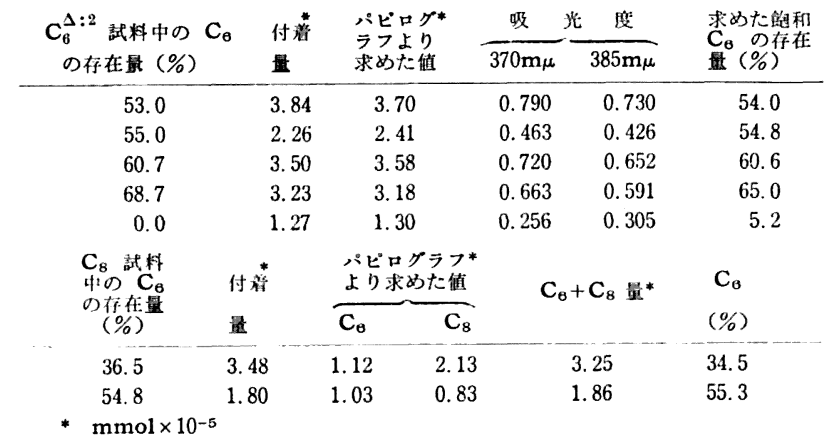

表 1 より明らかなように，溶媒抽出法より精度は悪いが $\pm 7 \%$ の誤差で定量することができた。本法は以上のと招り微量試料で 炭素数の違いによる分離と, 飽和, 不飽和モノェンおよびジェン の半定量ができる利点がある。

3.1ナタネ油を酸化したときに生ずる揮発性カルボニル化合 物

すでに,ナタネ油を酸化したとき生ずる揮発性カルボニル化合 
物について，その定量法および検索を従来行なってきたが，本法 を用いて分析した結果を比較するため次の実験を行なった。

精製ナタネ油 $300 \mathrm{~g}$ をスリ合せ三つロフラスコに入れ, $70 \mathrm{ml}$ $\min$ の速さで乾燥空気を送入し, $96 \pm 1^{\circ} \mathrm{C}$ に保った恒温浴中で 酸化した。発生する揮発性 カルボニル化合物は 2,4-DNP の 2 $\mathrm{N}$-塩酸飽和溶液を入れたトラップ中に導き捕集した。捕集物は, 前報1)のように操作してモノカルボニル化合物のみのフラクショ ン部を得た。これをベンゼン溶液として紫外吸収スペクトルを測 定し, $358 \mathrm{~m} \mu$ の吸光度を用いて算出するとナタネ油 $300 \mathrm{~g}$ から 酸化時間 12 時間をでに $227.95 \mathrm{mmol}$ の揮発性カルボニル化合物 が発生した。既報1) の計算式を用いて飽和カルボニル化合物と不 飽和カルボニル化合物とを求めた。飽和カルボニル化合物は $63.57 \%$ ，不飽和カルボニル化合物は $36.41 \%$ であった。

このものを試料として本法で分離定量を行なった。すなわち, ナタネ油から発生したモノカルボニル化合物の 2,4-DNPH をべ ンゼンにとかして一定濃度とした。この中よりミクロピペットで 一定量とり出して口紙に付着させた。展開終了後風乾し，370 $\mathrm{m} \mu$ の波長を用いて各分離した斑点のパピログラフを求めた。そ の結果の一例を図 5 に示した。

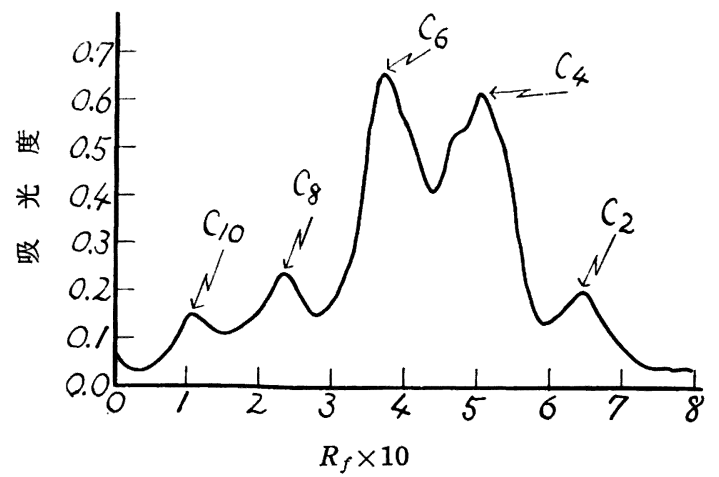

図 5 ナタネ油より得た揮発性カルボニル 化合物のパピログラフ

図中の $\mathrm{C}_{2} 、 \mathrm{C}_{4} \cdots \cdots$ の邹号はそれぞれアセトアルデヒド, ブチル アルデヒド…... 2,4-DNPH の $R_{f}$ 值に一致するるのを示す。
図 5 の結果から図 4 に示した “付着した量と吸光度曲線下の面 積との関係”を用いて, 揮発して来たカルボニル化合物中の炭素 数別の組分けを求めると表 2 のごとくである。

\begin{tabular}{|c|c|c|c|}
\hline 栄素数a) & 面棈比事b) (\%) & 炭亲数 $\left.{ }^{a}\right)$ & 面䅡比率b $(\%)$ \\
\hline $\mathrm{C}_{2}$ & 10.9 & $\mathrm{C}_{8}$ & 11.2 \\
\hline $\mathrm{C}_{4}$ & 33.5 & $\mathrm{C}_{10}$ & 6.5 \\
\hline $\mathrm{C}_{6}$ & 37.5 & & \\
\hline
\end{tabular}

つぎに各斑点について最高吸光度を示す場所に口紙を微動して 調節固定し，310〜 450 m $\mu$ の紫外吸収スペクトルを測定した。 $2 \cdot 3 \cdot 3$ に記した計算式を用いて, 各斑点中の飽和カルボニル化合 物と不飽和カルボニル化合物とを定量した。その結果を表 3 に示 した。

表 3 分離した斑点中の各アルデヒドの定量結果

\begin{tabular}{|c|c|c|c|c|c|}
\hline & & \multirow[b]{3}{*}{$370 \mathrm{~m} \mu$} & & \multirow{3}{*}{$\frac{\text { 度 }}{405 \mathrm{~m} \mu}$} & \multirow{3}{*}{$\begin{array}{l}\text { 䬲和カル } \\
\text { ホニル化 } \\
\text { 合物 }(\%)\end{array}$} \\
\hline & & & 光 & & \\
\hline & & & $385 \mathrm{~m} \mu$ & & \\
\hline $\mathrm{C}_{4}$ & に相当する斑点 & 0.720 & 0.604 & 0.405 & 68.3 \\
\hline $\mathrm{C}_{8}$ & " & 0.792 & 0.773 & 0.581 & 35.5 \\
\hline $\mathrm{C}_{8}$ & $" \prime$ & 0.581 & 0.596 & 0.492 & 19.2 \\
\hline $\mathrm{C}_{10}$ & $"$ & 0.411 & 0.438 & 0.382 & 13.5 \\
\hline （注） & $\begin{array}{l}\text { シェンンアルデヒ } \\
\text { ったことを付記 }\end{array}$ & $\begin{array}{l}\text { 锺発量は畐は } \\
\text { おく。 }\end{array}$ & く分析結 & を左右する & でには至らなか \\
\hline
\end{tabular}

表 2 扣よび表 3 の結果から揮発性カルボニル化合物中の飽和カ ルボニル化合物の存在量（\%) を求めると $68.0 \%$ となる。

溶液抽出法で紫外吸収スペクトルを測定し， $358 \mathrm{~m} \mu, 373 \mathrm{~m} \mu$ に扰ける吸光度より算出した值は, 飽和カルボニル化合物量は揮 発カルボニル化合物に対して $63.6 \%$ であった結果と比べ, 本法 は半定量法としては比較的一致した值である。

ナタネ油を前記した条件で酸化した場合，発生したカルボニル 化合物 $222.95 \mathrm{mmol}$ 中 $\mathrm{C}_{4}$ および $\mathrm{C}_{6}$ で占める割合は約 $70 \%$ であり，この5ち $\mathrm{C}_{4}$ に相当するアルデヒドは $68 \%$ が飽和化合 物で，また $\mathrm{C}_{6}$ に相当するアルデヒドは, 約 $36 \%$ が飽和であっ た。

（本報の一部は日本化学会, 日本油化学会共催, 油化学討論会 で発表した） 